\title{
Concha bullosa
}

\author{
Alper Nabi Erkan
}

Received: 7 March 2013/Accepted: 17 April 2013/Published online: 24 April 2013

(C) Springer-Verlag Berlin Heidelberg 2013

To the Editor,

We read the article titled "Concha bullosa surgery and the distribution of human olfactory neuroepithelium" which was written by Apuhan et al. [1] in your journal. It is a good clinical research. It is important to know for endonasal surgery that the olfactory neuroepithelial is situated within the olfactory cleft of the nasal cavity and extends to the upper portion of the nasal septum and onto the superior and middle turbinates to varying degrees [2]. Apuhan et al. [1] had found olfactory nerve tissue at least in the medial part of the middle concha bullosa than the other parts of concha in their research and they suggest to open medial part of the concha bullosa in concha bullosa surgery. We agree with their opinion. But in cases of concha bullosa with chronic sinusitis, the main problem could be obstruction of the middle meatus from concha bullosa. To solve this problem, we must choose the lateral lamella of the concha bullosa to open. In situation like this, lateral lamella of the concha bullosa could be sacrificed.
Conflict of interest I have no financial relationship with the organization that sponsored the research.

\section{References}

1. Apuhan T, Yıldırım YS, Şimşek T, Yılmaz F, Yılmaz F (2013) Concha bullosa surgery and the distribution of human olfactory neuroepithelium. Eur Arch Otorhinolaryngol 270:953-957

2. Lane AP, Gomez G, Dankulich T, Wang H, Bolger WE, Rawson NE (2002) The superior turbinate as a source of functional human olfactory receptor neurons. Laryngoscope 112(7):1183-1189
A. N. Erkan $(\square)$

Department of Otorhinolaryngology, Baskent University,

Baraj Yolu 1. Durak, Seyhan, 01110 Adana, Turkey

e-mail: alpernabierkan@yahoo.com 